\title{
TECHNIQUES TO TEACH LAW TERMS IN ENGLISH LESSONS
}

\author{
Akmal Akramjonovich Davranov \\ Academic Lyceum Under Tashkent State University Of Law, Uzbekistan
}

\section{ABSTRACT}

The article discusses the features of teaching legal vocabulary in English to law students. When studying English, students of law faculties have many difficulties, since it is necessary to master not only the basic level of the language, but also the special legal terminology used in the practice of the legal language. To do this, students need to be introduced not only to grammar and vocabulary, but also to the specifics of the legal realities international legal systems. Legal terminology reflects the legal culture of every country.

KEYWORDS: - Legal English, law terms, legal vocabulary, international legal system, learning techniques, word cloud.

\section{INTRODUCTION}

In order to form intercultural communication among law students in the process of teaching English, first of all, they get acquainted and work with authentic material in the classroom. Authentic material helps to form knowledge and ideas about the legal culture of the language being studied. If we are talking about learning English, then in this case we are comparing the legal cultures of Englishspeaking countries. The legal language is a complex phenomenon, as it makes it difficult for specialists, namely lawyers, to use it in English. Legal texts use unusually long sentences, certain conditions, a large number of passive constructions, grammatical phenomena. As a rule, in legal texts, verbal combinations are represented by non-personal verb forms, the most typical of which has the structure "modal verb (usually shall) + be + past participle".
The verb shall in the texts of laws expresses a duty, an obligation, and is not an indicator of the future tense (for example, husband shall pay to wife spousal support in the sum of ...). Also, special legal terminology is a great difficulty in the legal field in English. It follows from the theory of legal sciences that there are national legal terms and international legal ones. International legal terms are contained in international documents (the Universal Declaration of Human Rights of 1948; the International Covenant on Civil and Political Rights of 1966), and national legal terms are contained in the normative legal acts of a certain country and express certain requirements and regulations of a particular country.

\section{Materials AND METHOdS}

I would like to offer you some types of vocabulary learning techniques that can be included in English 
CURRENT RESEARCH JOURNAL OF PHILOLOGICAL SCIENCES 2(12):

216-220, December 2021

DOI: https://doi.org/10.37547/philological-crjps-02-12-41

ISSN 2767-3758

(C2021 Master Journals

Crossref do

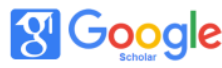

Accepted26 $6^{\text {th }}$ December, 2021 \& Published $31^{\text {th }}$ December, 2021

classes for law students.

Research by linguists shows that vocabulary training should contain the following components:

- Definition and contextual information about the word.

- Repeated acquaintance with the word in various contexts.

- $\quad$ Encouraging active self-study of new words by students.

Graphic organizer technique for teaching vocabulary is effective for learning law vocabulary. Draw an A4 sheet into four rectangles. At the intersection of these lines, write a word or phrase that you need to remember. Sign each rectangle starting from the top left clockwise:

Description: Define the term using your own words. Characteristics: Give at least 3 interesting characteristics of the term.

Synonym: What is it like?

Antonym: What is it not like?

Students, using their vocabulary that they learned from reading passage, fill in rectangles. Supplement them with drawings or diagrams.

The technique of memorization "Graphic Organizer" helps students to learn new words. If you define new lexical units in your own words, give examples from familiar situations and visual images, then any word will be imprinted in your memory for a long time.

How to work with a graphic organizer in the classroom:

Preparation. Define a list of words to study within a specific topic. Working with a group of 3-4 students, give each group a task to study one word.

Mini-demonstration. Explain to the class what a graphic organizer is and tell them how to fill in the graphs.

Group work. Make it easier for students to work on new words by discussing the word given to them with each group. Use leading questions to push the group to think in the direction you need.

Discussion in the lesson. Give a task to one student from the group to present his word. Allow members of different teams to communicate with each other and get acquainted with other words. This will take 2-3 minutes, so as not to interrupt the rhythm of the lesson.

Another strategy is Word/tag cloud. A tag cloud is a collection of keywords or information selected from an excerpt or chapter that students are going to read. This strategy gives students a chance to connect new words or information with the main idea of the reading text. It helps to retell the main content of the text well. Teacher can find enough resources on the web to help analyze the text and create a word cloud. The teacher can print the cloud and bring it to the lesson. But if there is an interactive whiteboard in the classroom, it will simplify the process of creating a cloud. How to use the tag cloud in foreign language lessons?

For text analysis. The teacher can draw students' attention to the frequency of words used in the text (the most frequently used ones are highlighted in a larger font). Or compare texts using word clouds. To guess the story based on the words presented in the cloud. To conduct a simple survey. For example, at home, students had to work with a new text. The teacher creates a cloud of words based on this text. Students read out the words whose meaning they have learned. In the lessons of repetition of any topic. The teacher demonstrates a cloud of the words of the topic, and the students repeat them. Create sentences or phrases with them.

Another technique is named as Interview with the word. Why not turn working on vocabulary into a game? With this strategy, students will repeat and summarize the knowledge gained while studying a certain topic. Choose keywords that are important for understanding the topic. Divide the class into groups of 2-4 people. 
CURRENT RESEARCH JOURNAL OF PHILOLOGICAL SCIENCES 2(12):

216-220, December 2021

DOI: https://doi.org/10.37547/philological-crjps-02-12-41

ISSN 2767-3758

(C)2021 Master Journals

\section{Crossref do) 81 Google}

Accepted26 ${ }^{\text {th }}$ December, 2021 \& Published 31 th December, 2021

Give each team a word and a list of interview questions. Other teams should not know what the opponents' word is. Ask students to "become" the word and write answers to the questions. Without revealing the words, the teacher or student acts as an interviewer and asks questions, and the team members read their written answers. After the interview, the class guesses the word.

\section{Results}

International legal acts have the greatest legal force than the normative legal acts of a certain country. It should be noted here that in the modern world there are several legal systems and absolutely identical national systems of law do not exist. In this regard, the language of each nation contains its own legal terms and concepts. The more different legal systems are from each other, the more different the concepts reflecting these systems are, respectively. And this fact naturally forms differences in legal terminology. This difference comes from the legal mentality of representatives of different legal cultures. A significant role is played by the difference in codification, laws and the system of offenses and punishments of different countries, which in turn creates a different attitude of citizens of different legal cultures to the law. In England, traditions are observed even in the legal sphere. The existing legislation of England in the field of the organization of the structure of the country's system, law enforcement agencies and the modern judicial system has been in force since the 5th centuries to this day. When we talk about the US legal system, it is conditional, since there is no unified national system of law there, and it has never been there. Each state has its own legal system, i.e. 50 state and 1 federal. The entire legal system of the United States is a mixture of several legal systems, since the system of American law was greatly influenced by English common law, and only then an attempt was made to codify the legislation.
Another interesting fact in legal English is the use of certain rare words in the vocabulary, such as hereon (on this document, on this basis), thereof (from this, from that), whereof (about which, from which), wherever (by virtue of which, on the basis of which, by which), herewith (hereby, by this, hereby (reported)), thereunder (by virtue of this law, contract, in accordance with this) and many others that are used in legal English in order to avoid repetition of any names or phrases (for example: "the parties here" instead of "the parties to this contract").

\section{Discussions}

In English and American criminal law, historically there was a certain classification of crimes according to the severity of the crime committed. Initially, it coincided in English and American law. All crimes were divided into felonies, misdemeanours and treasons with the generic term crime. Felony (fee - feudal possession and lon price) is a category of serious crimes in the criminal law of England, which were punishable by death or outlawing with confiscation of the property of criminals in favor of their lords. Felony included: blackmail, murder, manslaughter, burglary, larceny, housebreaking, bigamy, rape, incest, abortion, adbuction. The categories of the least dangerous crimes bordering on administrative offenses (transgressions, trespasses) belong to misdemeanor. These included: conspiracy, riot, malicious damage, barratry, perjury, fraud, false pretences, libel, assault, theft, embezzlement. Treasons were classified as crimes against the Government (high treason). These included: high treason, treachery, petit treason, war treason. The most serious category of crime in the criminal law of England was "high treason", which ended with the death penalty. According to the Statute of Treason of 1351 - 1352, the following compositions belonged to the category of grave treason: murder 
CURRENT RESEARCH JOURNAL OF PHILOLOGICAL SCIENCES 2(12):

216-220, December 2021

DOI: https://doi.org/10.37547/philological-crjps-02-12-41

ISSN 2767-3758

(C)2021 Master Journals

Crossref do

gil Google

Accepted26 ${ }^{\text {th }}$ December, 2021 \& Published 31 th December, 2021

or simple intent to kill the king, queen, their eldest son; rape of the queen, eldest daughter or wife of the eldest son of the king; waging war against the king in his kingdom or joining the enemies of the king; the murder of the chancellor, treasurer or any judge in the performance of their duties; forgery of state seals, counterfeiting. Such a classification of crimes existed in English and American law until 1967, when the Law on Criminal Law was adopted, which established a new classification according to the object of the crime. In English legal terminology, the generic term became offense. And the term "crime" began to denote concepts previously designated by the concepts felony and misdemeanor. Instead of the terms felony, misdemeanor, treason, the concepts included in the modern micro-field "crimes" for the object of the crime are used: crime - crimes against the state (high treason, conspiracy, treachery, petit treason, war treason, praemunire, sedition); crimes against justice (barratry, riot, perjury, malicious damage, fraud); crimes against religion (blasphemy, misance); crimes against reputation (false pretenses, libel, entry); crimes against security (assault, manslaughter, blackmail, murder, rape, abduction), crimes against morality (abortion, bigamy, incest); crimes against property (burglary, abbrochment, larceny, forgery, housebreaking, arson, embezzlement, robbery, pillage, theft). Also, the great difficulty for future lawyers in communicating in English in the professional sphere will be caused by terms that do not have a direct translation into other languages. For example, the word nuisance does not lend itself to direct translation in the legal field (in the dictionary it gives the meaning - a person, thing, or circumstance causing inconvenience or annoyance). You should also pay attention to such a feature that in legal documents you can find such concepts as liability and responsibility. These terms are understood the same way as "responsibility", but they give different meanings. Responsibility is a broader concept and is more often used in criminal and international law, and liability provides for material liability, which is regulated by civil law. There is a lot of legal terminology that contains a culturological component of meaning and to which an equivalent definition must be used. Thus, the phrase "Miranda rule/warning", which is defined as "the human right not to testify in the absence of a lawyer" is widely used in American legal practice. This phrase contains a cultural component, as it is connected with the judicial precedent of 1966, when the Supreme Court of Arizona invalidated the confessions of the accused named Miranda, received from him by the police in the absence of a lawyer. Since then, the "Miranda rule" has been in effect everywhere, without being associated with this court case.

\section{Conclusion}

In conclusion I want to share my opinion that the main idea of teaching intercultural communication to law students is to study and compare different legal cultures of the countries of the studied language and native. Only after studying the legal culture of the countries of the studied language can you master the legal terminology in English, which will mean mastering the professional competence of a future lawyer. Lawyers who have decided that they necessarily need knowledge of English in their work mistakenly think that general English will be quite enough. Such people really know the language well, have studied it at a university or at special courses and, perhaps, have a high level of proficiency. But even a strong intermediate or higher degrees of general English will only be a good help and foundation, but will not replace the study of a highly specialized language. Since a lawyer can have many specializations, then the professional language will have its differences depending on the chosen field of work. Business law, contractual, tax, family, economic, criminal and 
CURRENT RESEARCH JOURNAL OF PHILOLOGICAL SCIENCES 2(12):

216-220, December 2021

DOI: https://doi.org/10.37547/philological-crjps-02-12-41

ISSN 2767-3758

(C)2021 Master Journals

crossref do) 8: Google

Accepted26 ${ }^{\text {th }}$ December, 2021 \& Published 31 th December, 2021

other types will include the study of not only different topics, but also words, phrases, expressions and constructions.

Overall, teaching law term in English lessons is challenging but rewarding since it involves both language skills and knowledge of law terms. Teachers and students gain much new knowledge in these lessons.

\section{REFERENCE}

1. Walker R.J. The English Legal System. Butterworths, London. 1985

2. Martin E. A. \& Law J. A Dictionary of Law. Sixth edition. Oxford University Press. 2006

3. Wyatt R. Check your English Vocabulary for Law. Third Edition. A \& C Black, London. 2006

4. Gude K. \& Duckworth M. Proficiency Masterclass: Student's Book. Oxford: Oxford University Press, 2009 